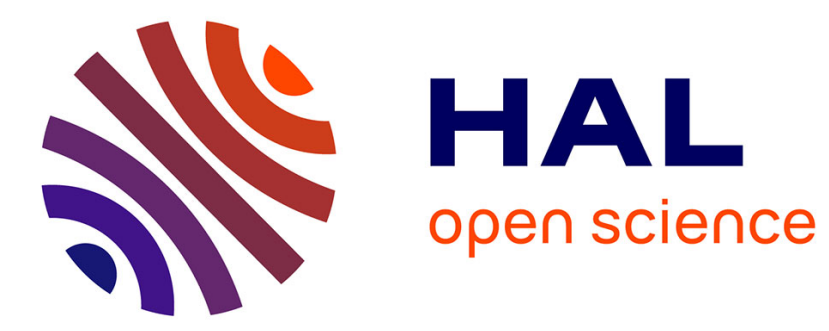

\title{
Stimulation of milk synthesis in the rabbit by fish pituitary extract
}

\author{
Patrick Prunet, L. M. Houdebine, C. Delouis, Bernard Breton
}

\section{To cite this version:}

Patrick Prunet, L. M. Houdebine, C. Delouis, Bernard Breton. Stimulation of milk synthesis in the rabbit by fish pituitary extract. Journal of Endocrinology, 1979, 83 (3), pp.393-400. 10.1677/joe.0.0830393 . hal-01601000

\section{HAL Id: hal-01601000 https://hal.science/hal-01601000}

Submitted on 2 Jun 2020

HAL is a multi-disciplinary open access archive for the deposit and dissemination of scientific research documents, whether they are published or not. The documents may come from teaching and research institutions in France or abroad, or from public or private research centers.
L'archive ouverte pluridisciplinaire HAL, est destinée au dépôt et à la diffusion de documents scientifiques de niveau recherche, publiés ou non, émanant des établissements d'enseignement et de recherche français ou étrangers, des laboratoires publics ou privés.

\section{다(1)(2)}

Distributed under a Creative Commons Attribution - ShareAlike| 4.0 International 


\title{
STIMULATION OF MILK SYNTHESIS IN THE RABBIT BY FISH PITUITARY EXTRACT
}

\author{
P. PRUNET, L. M. HOUDEBINE*, C. DELOUIS* \\ AND B. BRETON
}

Laboratoire de Physiologie des Poissons, and ${ }^{*}$ Laboratoire de.Physiologie de la Lactation, Institut National de la Recherche Agronomique, C.N.R.Z., 78350 Jouy-en-Josas, France

(Revised manuscript received 5 March 1979)

SUMMARY

The lactogenic properties of extracts of the pituitary glands of salmon and trout were evaluated by using the organ culture technique with rabbit mammary explants. Crude extracts and fractions obtained after chromatography on Ultrogel and selected for their capacity to compete with ovine prolactin in a rabbit mammary gland radioreceptor assay were added to the culture medium. The criteria of lactogenesis were lactose synthetase activity, casein synthesis, measurements of the concentration of casein messenger RNA and the histology of mammary glands. All these tests led to the conclusion that salmon and trout pituitary glands contain a prolactin-like principle capable of initiating milk synthesis in the rabbit mammary cell.

\section{INTRODUCTION}

Fish pituitary glands contain a prolactin-like hormone which affects the ionic balance in fish but which has no stimulatory activity on milk secretion in mammals. These conclusions have been drawn from experiments in which extracts of the pituitary glands of various fish were added to medium in which mouse mammary glands were cultured (Nicoll, Bern \& Brown, 1966; Nicoll \& Bern, 1968; Doneen, 1976; Farmer, Papkoff, Bewley, Hayashida, Nishioka, Bern \& Li, 1977) or where the extracts were injected intraductally into rabbit mammary glands (Chadwick, 1966a, b). Various fish pituitary extracts have been shown, however, to have stimulatory effects on the pigeon crop sac (Nicoll \& Bern, 1968) and on proliferation in the rabbit mammary gland (Chadwick, 1966b). Prunet, Djiane \& Breton (1977) reported that crude extracts of salmon pituitary glands are able to compete with ovine prolactin for rabbit mammary receptors. This observation suggested that the rabbit mammary gland might be stimulated by a prolactin-like factor present in the fish pituitary gland. The aim of the present work was to determine whether the prolactin-like factor detected by the radioreceptor assay exhibited lactogenic activity.

\section{MATERIALS AND METHODS}

Female 3- to 4-year-old salmon (Oncorhynchus tschawytscha) were used. After their arrival in the hatchery, they were kept in tap water for 2 months before spawning. Pituitary glands were collected at spawning after decapitation of the fish and they were frozen immediately in liquid nitrogen, lyophilized and stored under vacuum for 18 months at $4{ }^{\circ} \mathrm{C}$.

Trout (Salmo gairdneri) pituitary glands were collected just after decapitation when liver and muscle were also taken from the same fish. The lyophilized salmon pituitary glands and 
the fresh trout tissues were homogenized in 15 and 3 vol. Medium 199 respectively. The homogenates were centrifuged at $100000 \mathrm{~g}$ for $45 \mathrm{~min}$ at $4{ }^{\circ} \mathrm{C}$. The supernatant fractions were bioassayed directly or after dilution in culture medium.

The prolactin-like factor was partially purified by chromatography on Ultrogel AcA 54 (Industrie Biologique Française, Paris). Lyophilized salmon pituitary tissue (10 g) was homogenized in $500 \mathrm{ml} 50 \mathrm{mM}-\mathrm{Na}_{2} \mathrm{CO}_{3}$ containing $1 \mathrm{~mm}$-aminobenzamidine. The homogenate was kept for $3 \mathrm{~h}$ at $4{ }^{\circ} \mathrm{C}$ and centrifuged for $1 \mathrm{~h}$ at $100000 \mathrm{~g}$. The supernatant fraction was concentrated in Amicon cells on Diaflo PM 10 ultrafiltration membranes and dialysed against $25 \mathrm{~mm}$-Tris- $-\mathrm{HCl}$, pH 7.6, $150 \mathrm{~mm}-\mathrm{NaCl}$. This fraction was layered over an Ultrogel AcA 54 column (height $90 \mathrm{~cm}$, diameter $5 \mathrm{~cm}$ ) and eluted with the same buffer. Each fraction was lyophilized separately and stored at $-20^{\circ} \mathrm{C}$ until used. These fractions were dialysed against water just before addition to the culture medium. The prolactin-like factor was detected by a radioreceptor assay (Prunet et al. 1977), in which the competition curves between ovine prolactin and the fish pituitary factor were not parallel. A strict determination of the concentration of the prolactin-like factor using this method is thus impossible. For the sake of convenience, the values deduced from competition curves and expressed in ovine prolactin equivalents were those capable of inhibiting $50 \%$ of the binding of ${ }^{125}$ I-labelled ovine prolactin to receptors.

In some experiments, a crude extract devoid of glycoproteins was used. This fraction was obtained by homogenizing the tissue in $50 \mathrm{~mm}$-Tris- $\mathrm{HCl}, \mathrm{pH} 7.8,0.5 \mathrm{M}-\mathrm{NaCl}$. The homogenate was clarified by centrifugation and layered over a Concanavalin A Sepharose column (Pharmacia, Uppsala) in the same buffer containing $\mathrm{MgCl}_{2}, \mathrm{CaCl}_{2}, \mathrm{MnCl}_{2}$ at a concentration of $1 \mathrm{mmol} / \mathrm{l}$ each. After dialysis and lyophilization, the fraction not retained by the column was added to the culture medium.

Mammary explants from pseudopregnant rabbits were cultured for 1, 2 or 4 days in Medium 199 as described previously (Devinoy, Houdebine \& Delouis, 1978). In all cultures, the concentrations of insulin (Endopancrine, Paris) and cortisol (Roussel, Paris) were $5 \mu \mathrm{g} / \mathrm{ml}$. Ovine prolactin (NIH PS12, $35 \mathrm{i} . \mathrm{u} . / \mathrm{mg}$ ) kindly provided by NIAMDD, Bethesda, Maryland, U.S.A. and fish pituitary extracts were added at various concentrations. In the crude extracts, $1 \mathrm{mg}$ protein corresponds to about $5 \mathrm{mg}$ and $60 \mathrm{mg}$ lyophilized and fresh pituitary tissue from salmon and trout respectively. The protein concentrations in the fractions were determined by the method of Lowry, Rosebrough, Farr \& Randall (1951) using bovine serum albumin (Calbiochem, San Diego, U.S.A.) as standard. The lactose synthetase activity was determined by the method of Fitzgerald, Colvin, Mawal \& Ebner (1970).

The rate of casein synthesis at the end of the culture period was estimated after incubating the explants for $3 \mathrm{~h}$ with ${ }^{14} \mathrm{C}$-labelled amino acid. The labelled casein was precipitated with an anti-casein serum according to a technique described earlier (Houdebine, 1976) but with some slight modifications. The incubate contained $50 \mu 1$ extract from the labelled explants, $40 \mu \mathrm{g}$ rabbit casein and $200 \mu \mathrm{l}$ anti-casein serum concentrated three times by dissolving the lyophilized serum in one third of its initial volume. The mixture was incubated for $3 \mathrm{~h}$ at $37^{\circ} \mathrm{C}$ and overnight at $4{ }^{\circ} \mathrm{C}$. The immunoprecipitate was then collected after repeated washing, essentially as described previously (Houdebine, 1976). Each value is the result of a duplicate determination. The immunoprecipitated products were examined by polyacrylamide gel electrophoresis in the presence of sodium dodecyl sulphate (Houdebine \& Gaye, 1975).

The concentration of casein messenger RNA was estimated by hybridization with DNA complementary to casein messenger RNA (Devinoy et al. 1978). Results are expressed as the percentage of the DNA complementary to casein messenger RNA which had been hybridized to casein messenger RNA as a function of the concentration of RNA in the hybridization medium and the time $\left(\mathrm{R}_{0} . t\right)$ where $\mathrm{R}_{0}$ is the concentration of $\mathrm{RNA}$ in the hybridization medium and $t$ the duration of the reaction (Britten, Graham \& Neufeld, 1974). 
Mammary explants were also examined histologically (Jeulin-Bailly, Delouis \& Denamur, 1973).

\section{RESULTS}

\section{Chromatography of pituitary extracts}

After centrifugation, extracts of salmon pituitary tissue were fractionated on Ultrogel AcA 54. A prolactin-like factor, detected with the radioreceptor assay for lactogenic activity (Prunet et al. 1977), was eluted in the fractions corresponding to a molecular weight of about 22000 (Text-fig. 1). Various fractions rich in the prolactin-like factor were assayed for their lactogenic activity.

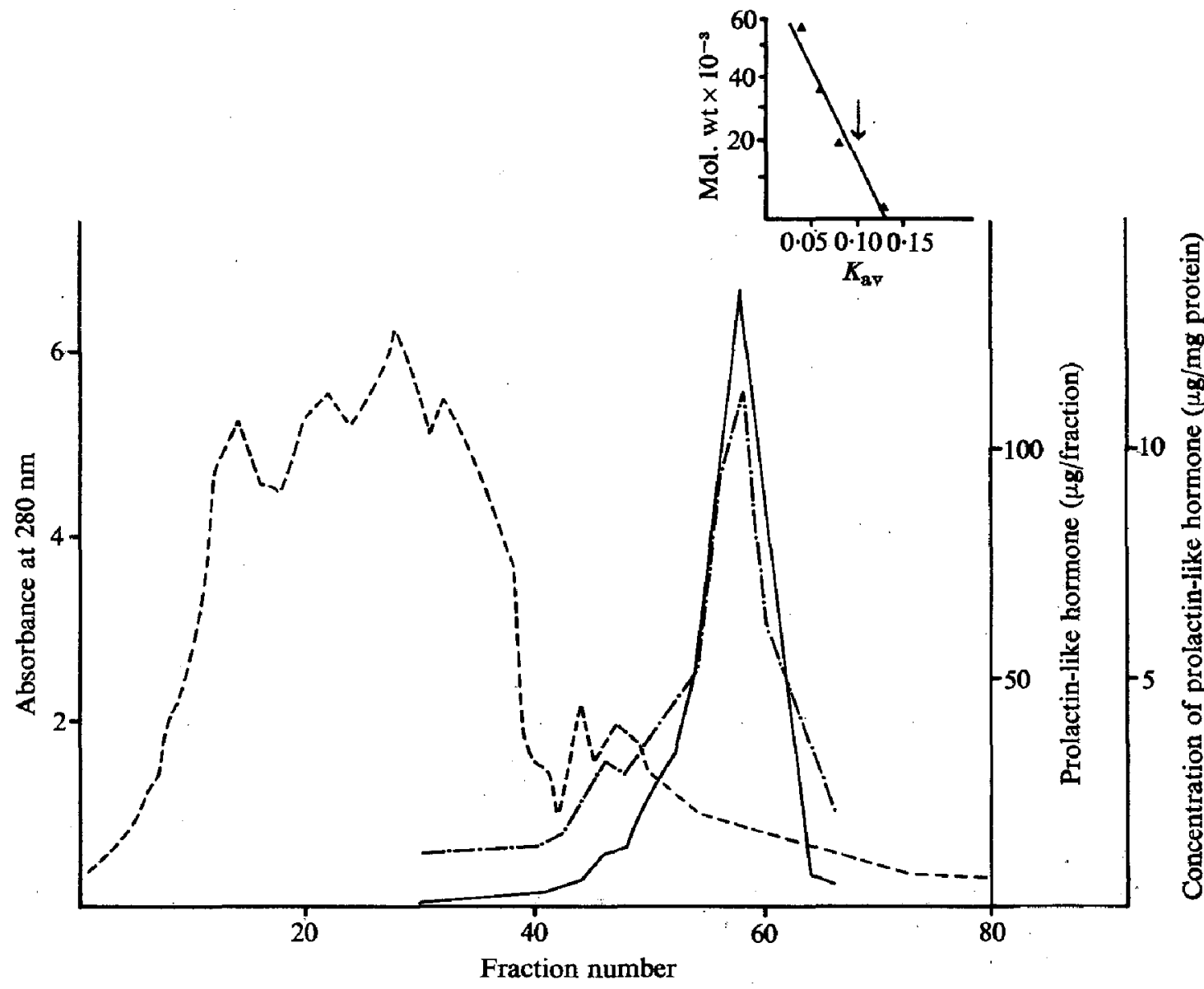

Text-fig. 1. Chromatography of salmon pituitary extracts on Ultrogel AcA 54. The crude extracts were centrifuged, concentrated, dialysed and layered over a column as described in Materials and Methods. Each fraction eluted from the column contained $15 \mathrm{ml}$. (-- ) Absorbance at $280 \mathrm{~nm}$; $(-\cdot-)$ prolactin $(\mu \mathrm{g} /$ fraction); (-) prolactin concentration $(\mu \mathrm{g} / \mathrm{mg}$ protein). In the insert, the position of the active prolactin-like factor, indicated by the arrow, is compared with four proteins of known molecular weight chromatographed on the same column (in decreasing order: horse serum albumin, ovalbumin, chymotrypsinogen, cytochrome c. Results are expressed as the logarithm of the molecular weight as a function of the partition coefficient $\left(K_{\mathrm{av}}\right)$.

\section{Lactose synthetase activity}

The lactose synthetase activity of the mammary explants was measured after 2 days of culture in the presence of various fish pituitary extracts. Crude extracts of both salmon or trout pituitary glands enhanced lactose synthetase activity. Only the results obtained with the lowest protein concentrations $(<1-1.5 \mathrm{mg}$ protein $/ \mathrm{ml}$ medium) were worthy of consideration. At the highest protein concentration (not shown) two side effects, a non-specific 
stimulation due to proteins and a toxic effect, modified the reliability of the response. However, in all cases, the values were greater than those in the control cultures (Table 1). The partially purified prolactin-like factor was more potent than the crude extracts in stimulating lactose synthetase activity (Table 2).

Table 1. Effect of extracts of various fresh tissues from trout and of lyophilized salmon pituitary tissue on lactose synthetase activity and casein synthesis in rabbit mammary gland cultured in medium containing insulin and cortisol $(5 \mu \mathrm{g} / \mathrm{ml}$ each). Results are means of duplicate determinations and are expressed as pmol $\left[{ }^{14} \mathrm{C}\right]$ lactose $/ 10 \mathrm{~min}$ per $\mathrm{mg}$ tissue and as percentage of labelled protein precipitated by antibody to rabbit casein

\begin{tabular}{|c|c|c|c|}
\hline $\begin{array}{l}\text { Experiment } \\
\text { no. }\end{array}$ & Medium & $\begin{array}{l}\text { Lactose synthetase } \\
\text { activity }\end{array}$ & Casein synthesis \\
\hline \multirow[t]{3}{*}{1} & $\begin{array}{l}\text { Control } \\
\text { Trout liver } \\
\quad(830 \mu \mathrm{g} / \mathrm{ml})\end{array}$ & $\begin{array}{l}0.09 \\
0.07\end{array}$ & $\begin{array}{r}6 \cdot 8 \\
12 \cdot 3\end{array}$ \\
\hline & $\begin{array}{l}\text { Salmon pituitary } \\
\text { tissue } \\
(124 \mu \mathrm{g} / \mathrm{ml})\end{array}$ & 0.25 & $14 \cdot 4$ \\
\hline & $\begin{array}{l}\text { Trout pituitary tissue } \\
\quad(400 \mu \mathrm{g} / \mathrm{ml})\end{array}$ & 0.25 & $14 \cdot 9$ \\
\hline \multirow[t]{4}{*}{2} & Control & 0.06 & $4 \cdot 4$ \\
\hline & $\begin{array}{l}\text { Bovine serum } \\
\text { albumin } \\
(100 \mu \mathrm{g} / \mathrm{ml})\end{array}$ & $0 \cdot 06$ & $4 \cdot 6$ \\
\hline & $\begin{array}{l}\text { Trout muscle } \\
(100 \mathrm{~kg} / \mathrm{ml})\end{array}$ & 0.06 & $6 \cdot 2$ \\
\hline & $\begin{array}{l}\text { Salmon pituitary } \\
\text { tissue } \\
(100 \mu \mathrm{g} / \mathrm{ml})\end{array}$ & $0 \cdot 13$ & $12 \cdot 5$ \\
\hline
\end{tabular}

\section{Casein synthesis}

The pituitary extracts were also tested for their ability to initiate casein synthesis in mammary explants. Crude extracts from salmon and trout pituitary glands stimulated the rate of casein synthesis (Table 1). The apparent stimulation by liver extract was probably not significant because this fraction markedly inhibited the synthesis of total mammary protein (not shown) thus leading to a low precision and to a possible overestimation of casein synthesis when it was expressed as the percentage of labelled proteins immunoprecipitated by the anti-casein serum. The lactogenic activity was more easily detected in the active fractions from the Ultrogel AcA 54 column. Several fractions eluted from the column before the peak (fractions 0-50) exhibited a low but significant lactogenic activity and a parallel capacity to compete with ${ }^{125} \mathrm{I}$-labelled ovine prolactin in the radioreceptor assay, possibly due to aggregated forms of the factor (not shown). In all cases, cortisol potentiated the effect of the prolactin-like factor (Table 2).

Salmon gonadotrophin purified by Breton, Prunet \& Reinaud (1978) exhibited no lactogenic activity (results not, shown).

The size of the response estimated by the test of casein synthesis was sometimes slightly lower than that determined by the measurement of lactose synthetase activity. This can be attributed to the fact that it was the lactose synthetase which was synthesized at the beginning of the culture and stored in the explants which was being measured, whereas it was only the capacity of the explants to direct the synthesis of casein for a short time at the end of the culture which was being estimated. This slight discrepancy between the two tests is commonly observed. To ascertain the specificity of the stimulation of casein synthesis the materials precipitated by the anti-casein serum were subjected to electrophoresis on polyacrylamide 
Table 2. Effect of the prolactin-like factor from salmon pituitary glands, partially purified by chromatography, on casein synthesis and lactose synthetase activity

(Various fractions eluted from the Ultrogel AcA 54 column (Text-fig. 1), selected for their high capacity to compete with ovine prolactin in a rabbit mammary gland radioreceptor assay, were added to the culture medium. Results of lactose synthetase activity and casein synthesis are means of duplicate determinations and are expressed as pmol $\left.{ }^{[4} \mathrm{C}\right]$ lactose $/ 10 \mathrm{~min}$ per $\mathrm{mg}$ tissue and as the percentage of labelled protein precipitated by an antibody to rabbit casein respectively.)

\begin{tabular}{|c|c|c|c|c|c|c|c|}
\hline & \multirow{2}{*}{$\underset{(5 \mu \mathrm{g} / \mathrm{ml})}{\text { Insulin }}$} & \multirow{2}{*}{$\begin{array}{c}\text { Cortisol } \\
(5 \mu \mathrm{g} / \mathrm{ml})\end{array}$} & \multirow{2}{*}{$\begin{array}{c}\text { Ovine } \\
\text { prolactin } \\
(\mathrm{ng} / \mathrm{ml})\end{array}$} & \multicolumn{3}{|c|}{ Fractions $(\mu \mathrm{g} / \mathrm{ml})$} & \multirow{2}{*}{$\begin{array}{l}\text { Casein } \\
\text { synthesis }\end{array}$} \\
\hline & & & & $52-53$ & $54-55$ & $56-57$ & \\
\hline \multirow[t]{6}{*}{ Expt 1} & + & - & - & - & 一 & - & $6 \cdot 0$ \\
\hline & + & - & - & - & - & 9 & $9 \cdot 2$ \\
\hline & + & - & - & - & - & 180 & $10 \cdot 6$ \\
\hline & + & + & - & - & - & 9 & $17 \cdot 8$ \\
\hline & + & + & - & - & - & 180 & $25 \cdot 1$ \\
\hline & + & - & 500 & - & - & - & 17.9 \\
\hline \multirow[t]{5}{*}{ Expt 2} & + & + & - & - & - & - & $11 \cdot 4$ \\
\hline & + & + & - & - & - & 9 & $11 \cdot 3$ \\
\hline & + & + & - & - & - & 180 & 18.2 \\
\hline & + & + & 20 & - & - & - & $20 \cdot 1$ \\
\hline & + & + & 200 & - & - & - & 20.8 \\
\hline \multirow[t]{5}{*}{ Expt 3} & + & - & - & - & - & - & $10 \cdot 7$ \\
\hline & + & - & - & - & 32 & - & 11.5 \\
\hline & + & - & - & - & 160 & - & $13 \cdot 4$ \\
\hline & + & - & 20 & - & - & - & $15 \cdot 1$ \\
\hline & + & - & 200 & - & - & - & $17 \cdot 1$ \\
\hline \multirow[t]{5}{*}{ Expt 4} & + & + & - & - & - & - & $9 \cdot 3$ \\
\hline & + & + & - & - & 32 & - & $12 \cdot 6$ \\
\hline & + & + & - & - & 160 & - & 20.8 \\
\hline & + & + & 400 & - & - & - & $16 \cdot 0$ \\
\hline & & & & & & & $\begin{array}{l}\text { Lactose } \\
\text { synthetase }\end{array}$ \\
\hline \multirow[t]{4}{*}{ Expt 5} & + & - & - & - & - & - & 0.09 \\
\hline & + & - & - & 6.8 & - & - & 0.20 \\
\hline & + & - & 20 & - & - & - & $0 \cdot 14$ \\
\hline & + & - & 200 & - & - & - & 0.32 \\
\hline \multirow[t]{4}{*}{ Expt 6} & + & - & - & - & - & - & 0.09 \\
\hline & + & - & - & - & 32 & - & 0.16 \\
\hline & + & - & - & - & 160 & - & 0.21 \\
\hline & + & - & 400 & - & - & - & 0.28 \\
\hline
\end{tabular}

gels in the presence of sodium dodecyl sulphate. With insulin + cortisol, there was no detectable casein synthesis. In the presence of either ovine prolactin or the prolactin-like factor, genuine casein was synthesized (Text-fig. 2).

\section{Concentration of casein messenger RNA}

Stimulation of casein synthesis by ovine prolactin is mediated by accumulated casein messenger RNA (Devinoy et al. 1978). In order to determine whether the synthesis of casein initiated by the fish pituitary factor was the result of a similar mechanism, casein messenger RNA was quantified after addition of an active fraction from the Ultrogel AcA 54 column to the culture medium. The hybridization kinetic curves shown in Text-fig. 3 indicate that the fish pituitary factor was able to provoke a marked accumulation of casein messenger RNA. Thus, in this respect, the fish pituitary factor exhibited a basic property of mammalian prolactin. 


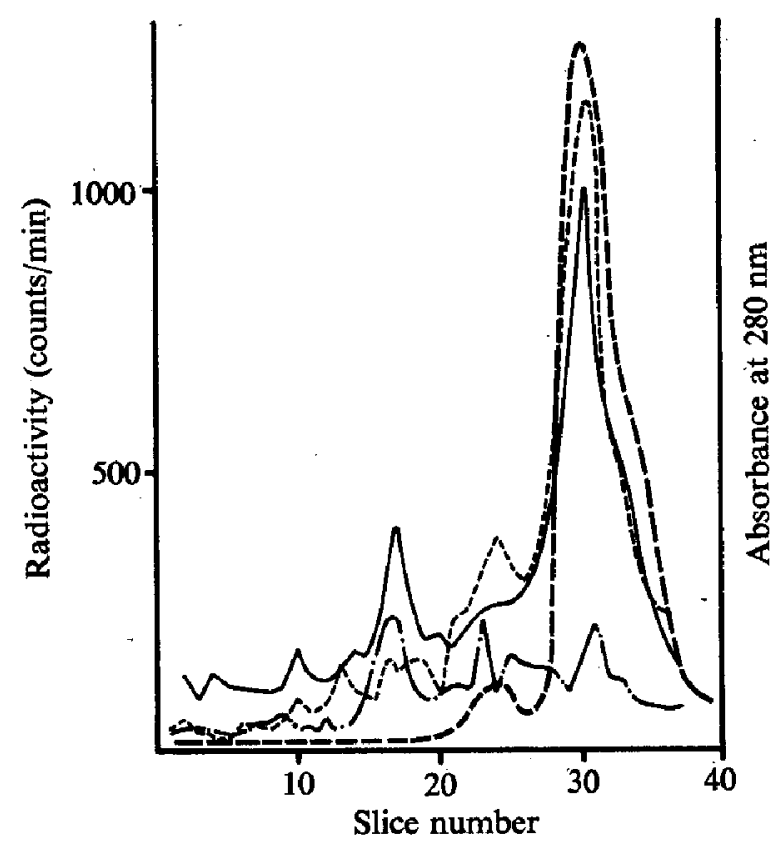

Text-fig. 2. Polyacrylamide gel electrophoresis of materials precipitated by an antiserum prepared against rabbit casein. The immunoprecipitates were dissolved and heated at $100{ }^{\circ} \mathrm{C}$ for $10 \mathrm{~min}$ in $0.1 \mathrm{M}$-sodium phosphate, $\mathrm{pH} 7.5$, containing $0.5 \%$ sodium dodecyl sulphate, $2 \%$ mercaptoethanol and 4 m-urea. After cooling, the fractions were layered over $7.5 \%$ acrylamide gels. At the end of the run, the gels were cut into $2.5 \mathrm{~mm}$ slices and the radioactivity was estimated by scintillation counting after elution overnight in $0.1 \mathrm{M}-\mathrm{NaOH}$. The percentages of labelled materials immunoprecipitated were: (- - $3 \cdot 5 \%$, insulin + cortisol; dotted line, 30.5\%, insulin + cortisol + ovine prolactin $(5 \mu \mathrm{g} / \mathrm{ml})$; solid line, $18.8 \%$, insulin + cortisol + a crude extract not retained on Concanavalin A Sepharose $(1 \mathrm{mg} / \mathrm{ml}$; see Materials and Methods). Dashed line, absorbance profile of the casein fraction used as antigen.

\section{Histology of the mammary explants}

The onset of milk synthesis is accompanied by a transformation of the mammary gland morphology; the acini become dilated and secretory products are progressively accumulated in the alveolar lumen. Crude extracts from various fish tissues were assayed for their capacity to initiate these phenomena (Plate). It may be seen that bovine serum albumin and a crude extract from trout muscle stimulated the secretory activity only slightly above the control level, in agreement with their effect on the synthesis of milk products. Crude extracts from salmon pituitary tissue were able to bring about a marked dilatation of the acini and a significant accumulation of milk in the lumen.

\section{DISCUSSION}

The present results demonstrate that the pituitary glands of salmon and trout contain a principle which exhibits a lactogenic property similar to that of ovine prolactin. This conclusion results from several independent tests using crude pituitary extracts and a partially purified factor selected for its capacity to compete with ovine prolactin for a receptor in the rabbit mammary gland. The prolactin-like factor has a molecular weight of about 22000 , similar to that of mammalian prolactins.

The lactogenic activity of the various fractions was compared with their capacity to compete with ${ }^{125}$ I-labelled ovine prolactin for binding to prolactin receptors in the radioreceptor assay. It was not possible to establish a tight correlation between these two parameters, although the richest fractions were in all cases the most active. This difficulty was not surprising. Indeed, the competition curves of ovine prolactin and fish pituitary extracts exhibit different slopes (Prunet et al. 1977) and the high concentrations of protein 


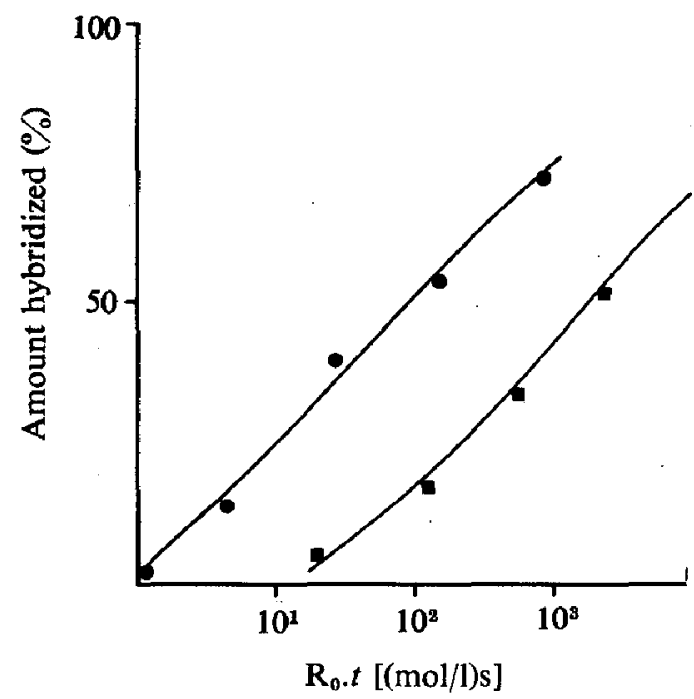

Text-fig. 3. Hybridization kinetic curves of casein messenger RNA determined with a DNA probe complementary to casein messenger RNA. At the end of each culture period, the RNA was extracted from about $800 \mathrm{mg}$ mammary explant tissue of each hormonal treatment. Various concentrations of this RNA were then incubated for $24 \mathrm{~h}$ at $65^{\circ} \mathrm{C}$ with a labelled DNA complementary to casein messenger RNA. At the end of this incubation the non-hybridized DNA was selectively digested with an $S_{1}$ nuclease. Each curve shows the percentage of the original DNA probe hybridized to the casein messenger RNA present in the total RNA extracted from the mammary explants. Results are expressed as a function of the concentration of RNA in the hybridization medium and the time $\left(R_{0} . t\right)$, where $R_{0}$ is the concentration of RNA in the hybridization medium and $t$ the duration of the reaction. In such figures the RNA fractions containing most casein messenger RNA are hybridized with the complementary DNA probe faster and at lower concentrations of total RNA. They give, therefore, the curves on the left hand side of the graph. The concentration of casein messenger RNA in each fraction is given by the transition point on the corresponding curve. Medium containing insulin + cortisol ( $\boldsymbol{\square})$; insulin + cortisol + and an active fraction from the Ultrogel AcA 54 column $(1 \mathrm{mg} / \mathrm{ml} ; \bullet)$.

in the culture medium interfere to some extent with the activity of the mammary explants. Only a further purification of the prolactin-like factor will provide an answer to the question.

Previous work has demonstrated that prolactin from tilapia (Sarotherodon (= Tilapia) mossambicus), when purified to homogeneity, is totally devoid of lactogenic activity (Doneen, 1976; Farmer et al. 1977). Explanations of this discrepancy are presently tentative at best and it should be noted that these experiments have been carried out using the pituitary glands of salmon and trout. These fish are generally considered to have preceded tilapia in evolution and it is, therefore, difficult to explain the discrepancy between species in a simple way. During the course of the purification, the prolactin from tilapia may have lost its lactogenic activity while maintaining a high capacity to control the movement of ions. Such a selectivity in the loss of activity would be somewhat surprising, although not impossible. Another possible explanation is that the purified prolactin from tilapia and the factor exhibiting the lactogenic property are two distinct entities. These factors have been selected independently by two tests relying on two different properties; the sodium-retaining activity (tilapia) and the binding to mammary receptors (salmon and trout). Thus the factor exhibiting the lactogenic property may have been eliminated during the isolation of tilapia prolactin.

Fish growth hormone would be expected to elute from Ultrogel AcA 54 in the same position as that observed for the lactogenic factor and, since prolactin and $\mid$ growth $/$ hormone are generally considered to have a common ancestor, it is possible that a salmon growth hormone with lactogenic activity may have been purified. Alternatively, the factor able to initiate milk synthesis may be like neither the prolactin characterized in tilapia nor the growth hormone. 
In terms of evolution, it has been proposed that the prolactin molecule acquired some stimulation properties long before the emergence of the corresponding target organ (Nicoll et al. 1966). The present work confirms this suggestion.

The excellent technical assistance of Mrs M. L. Fontaine, Mrs C. Puissant and $\mathrm{H}$. Grabowski is gratefully acknowledged. The authors wish to thank Professor $\mathbf{H}$. Clauser for his help in writing the manuscript. This work was supported by grants from D.G.R.S.T., C.N.R.S. and the Ministère de la Qualité de la Vie (no. 36.76).

\section{REFERENCES}

Breton, B., Prunet, P. \& Reinaud, P. (1978). Sexual differences in salmon gonadotrophin. Annales de Biologie Animale, Biochimie et Biophysique 18, 759-765.

Britten, R. J., Graham, D. E. \& Neufeld, B. R. (1974). Analysis of repeating DNA sequences by reassociation. In Methods in enzymology, vol. XXIX, part E, pp. 368-408. Eds L. Grossman \& K. Moldave. New York: Academic Press.

Chadwick, A. (1966a). Prolactin-like activity in the pituitary gland of the frog. Journal of Endocrinology 34, $247-255$.

Chadwick, A. (1966b). Prolactin-like activity in the pituitary gland of fishes and amphibians. Journal of Endocrinology 35, 75-81.

Devinoy, E.; Houdebine, L. M. \& Delouis, C. (1978). Role of prolactin and glucocorticoids in the expression of casein genes in rabbit mammary gland organ culture. Quantification of casein mRNA. Biochimica et Biophysica Acta 517, 360-366.

Doneen, B. A. (1976). Biological activities of mammalian and teleostean prolactins and growth hormones on mouse mammary gland and teleost urinary bladder. General and Comparative Endocrinology 30, 34-42.

Farmer, S. W., Papkoff, H., Bewley, T. A., Hayashida, T., Nishioka, R. S., Bern, H. A. \& Li, C. H. (1977). Isolation and properties of teleost prolactin. General and Comparative Endocrinology 31, 60-71.

Fitzgerald, D. K., Colvin; B., Mawal, R. \& Ebner, K. E. (1970). Enzymatic assay for galactosyl transferase activity of lactose synthetase and $\alpha$-lactalbumin in purified and crude system. Analytical Biochemistry 36, $43-61$.

Houdebine, L. M. (1976). Effects of prolactin and progesterone on expression of casein genes. Titration of casein mRNA by hybridization with complementary DNA. European Journal of Biochemistry 68, 219-225.

Houdebine, L. M. \& Gaye, P. (1975). Regulation of casein synthesis in the the rabbit mammary gland. Titration of mRNA activity for casein under prolactin and progesterone treatments. Molecular and Cellular Endocrinology 3, 37-55.

Jeulin-Bailly, C., Delouis, C. \& Denamur, R. (1973). Influence de l'oestradiol-17ß et de la progestérone au cours de l'induction par la prolactine et l'hormone de croissance de la différenciation lobulo-alvéolaire du tissu mammaire de brebis gestante en culture organotypique. Comptes Rendus Hebdomadaires des Séances de l'Académie des Sciences 277, 2525-2528.

Lowry, O. H., Rosebrough, N. S., Farr, A. L. \& Randall, R. S. (1951). Protein measurement with the Folin phenol reagent. Journal of Biological Chemistry 193, 265-275.

Nicoll, C. S. \& Bern, H. A. (1968). Further analysis of the occurrence of pigeon crop sac stimulating activity (prolactin) in the vertebrate adenohypophysis. General and Comparative Endocrinology 11, 5-20.

Nicoll, C. S., Bern, H. A. \& Brown, D. (1966). Occurrence of mammotrophic activity (prolactin) in the vertebrate adenohypophysis. Journal of Endocrinology 34, 343-354.

Prunet; P., Djiane, J. \& Breton, B. (1977). Application of a radioreceptor assay for lactogenic activity to the detection of fish prolactin-like hormone. Journal of Endocrinology 73, 391-392.

\section{DESCRIPTION OF PLATE}

Magnification $\times 200$. Staining: haemalum, eosin and Light green.

Histology of rabbit mammary explants cultured for 4 days in Medium 199 containing insulin and cortisol $(5 \mu \mathrm{g} / \mathrm{ml}$ of each).

Fig. 1. Insulin + cortisol only.

Fig. 2. Insulin + cortisol + bovine serum albumin $(1 \mathrm{mg} / \mathrm{ml})$.

Fig. 3. Insulin + cortisol + crude extract from salmon pituitary gland not retained on Concanavalin $\mathbf{A}$ Sepharose $(1 \mathrm{mg} / \mathrm{ml}$; see Materials and Methods).

Fig. 4. Insulin + cortisol + ovine prolactin $(5 \mu \mathrm{g} / \mathrm{ml})$.

Fig. 5. Insulin + cortisol + crude extract from trout muscle $(1 \mathrm{mg} / \mathrm{ml})$. 

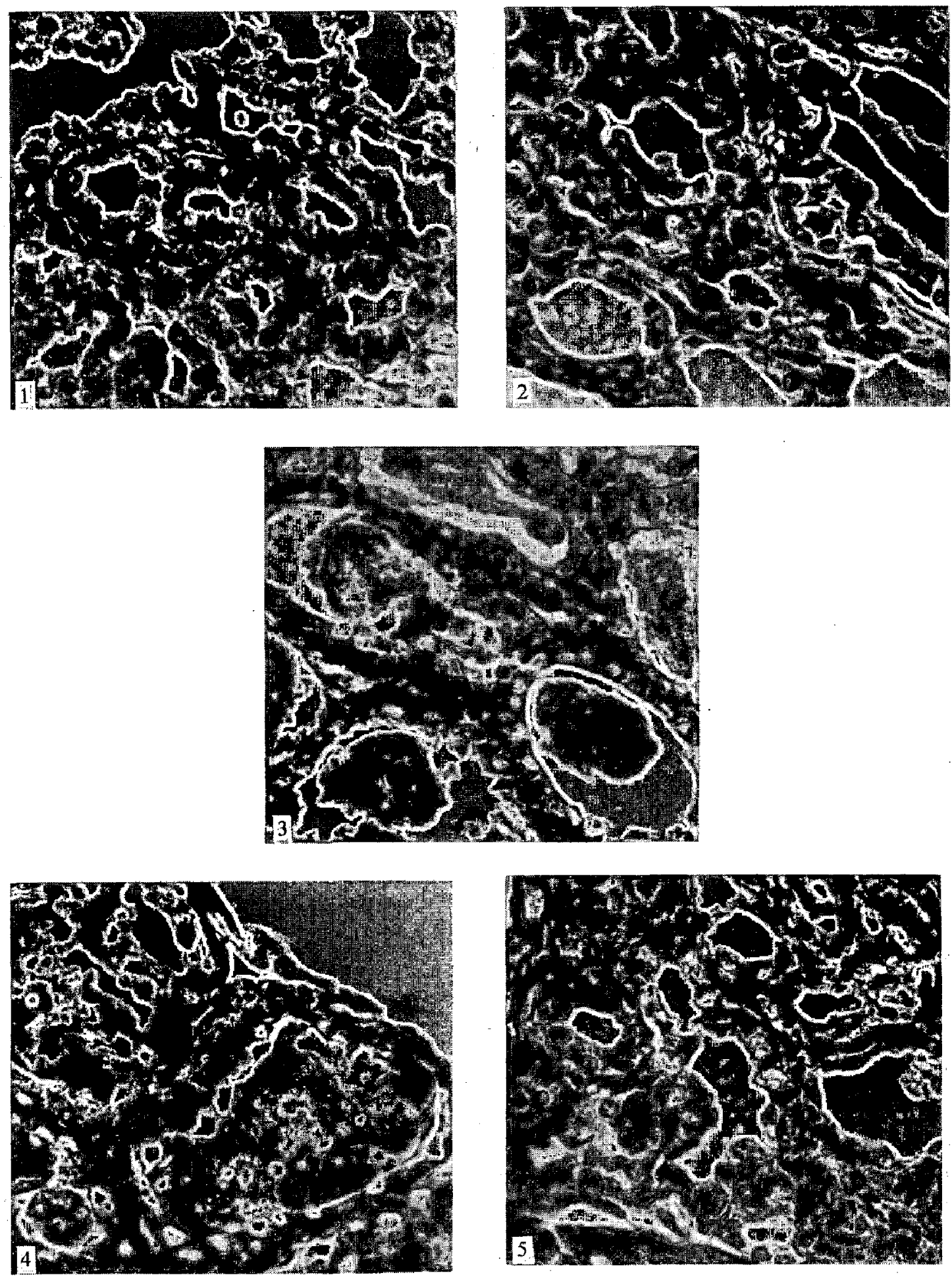